\title{
EFEKTIVITAS PEMBERIAN BAKTERI Bacillus polymyxa MELALUI PAKAN TERHADAP IMUNITAS NON SPESIFIK UDANG VANNAMEI (Litopenaeus vannamei)
}

\author{
Muhammad Haris Kurniawan, Berta Putri*1, dan Yeni Elisdiana*2
}

\begin{abstract}
The addition of Bacillus polymyxa bacteria in the feed as immunostimulant is one of the efforts of disease prevention on vannamei shrimp (Litopenaeus vannamei). The aimed of this research was to know the effectivity of the use of Bacillus polymyxa bacteria in feed towards the non-specific imunity of vannamei shrimp. This research consisted of 4 treatments namely feed with the density of Bacillus polymyxa bacteria $0 \mathrm{cell} / \mathrm{ml}$ as control $(\mathrm{A}), 10^{4} \mathrm{cell} / \mathrm{ml}(\mathrm{B}), 10^{6} \mathrm{cell} / \mathrm{ml}(\mathrm{C})$ and $10^{8} \mathrm{cell} / \mathrm{ml}(\mathrm{D})$ and each treatment is repeated 3 times. This research has been done in 15 days. Parameters that observed this research were total haemocyte count (THC), phagocytosis activity, differential haemocyte count (DHC) and water quality. The results showed that the addition Bacillus polymyxa bacteria of $10^{6}$ cell/ml was able to improve THC value $6,6 \times 10^{7} \mathrm{cell} / \mathrm{ml}$ on the day 10 . The DHC value was in the normal range which is hyalin cell was $52-89 \%$ and granular cell was $11-48 \%$. The quality of water maintenance media during this research was in the normal range there were temperature $27,2-28,1^{\circ} \mathrm{C}, \mathrm{DO} 3,70-3,91 \mathrm{ppm}, \mathrm{pH} 3,70$ 3,91, and salinity 30-35 ppt.
\end{abstract}

Keywords: Litopenaeus vannamei, immunostimulant, Bacillus polymyxa, non spesific imunity

\section{Pendahuluan}

Udang vanamei (Litopenaeus vannamei) merupakan salah satu komoditas unggulan dalam sektor perikanan budidaya yang permintaannya terus meningkat dan berkembang pesat. Berdasarkan data sementara statistik Direktorat Jenderal Perikanan Budidaya (DJPB) tahun 2015, produksi udang vannamei mencapai 17,6 juta ton. Dalam memenuhi permintaan pasar akan udang vannamei memberikan dampak yang positif terhadap perkembangan sistem budidaya udang putih dari sistem tradisional sampai sistem intensif. Semakin berkembang sistem budidaya maka padat tebar yang digunakan semakin meningkat. Hal tersebut dapat berpotensi menyebabkan berkembangnya penyakit.

Sistem imunitas pada udang masih sangat primitif dan tidak memiliki sel memori, tidak sama

\footnotetext{
${ }^{1}$ E-mail: berta.putri@fp.unila.ac.id

${ }^{2}$ Jurusan Perikanan dan kelautan, Fakultas Pertanian, Universitas Lampung

Jl. Prof. S. Brodjonegoro No.1 Gedong Meneng Bandar Lampung 35145
} 
halnya dengan hewan vertebrata lainnya yang sudah mempunyai antibodi spesifik dan komplemen. Sistem imunitas pada udang tidak mempunyai immunoglobulin yang berperan dalam mekanisme kekebalan, udang hanya mem-punyai sistem kekebalan alami. Udang mempunyai daya tahan alami yang bersifat non spesifik terhadap organisme patogen berupa pertahanan fisik (mekanik), kimia, seluler dan humoral. Daya tahan alami ini dipengaruhi oleh faktor genetik dan lingkungan, sehingga terdapat tingkatan yang berbeda-beda bergantung strain, lingkungan pemeliharaan, spesies maupun famili (Ridlo \& Pramesti, 2009).

Sistem imun udang bergantung pada sistem pertahanan non spesifik sebagai pertahanan terhadap infeksi (Lee \& Shiau, 2004). Pertahanan pertama terhadap penyakit pada udang dilakukan oleh hemosit melalui fagositosis, enkapsulasi dan nodule formation (Ridlo \& Pramesti, 2009). Hemosit merupakan faktor yang sangat penting dalam sistem pertahanan seluler yang bersifat non spesifik. Infeksi yang sering terjadi adalah infeksi bakterial (Kharisma \& Abdul, 2012). Selama ini, penanggulangan penyakit infeksi bakteri pada udang masih banyak menitikberatkan kepada upaya pengobatan setelah infeksi menyerang. Upaya-upaya pencegahan yang cukup efektif untuk meningkatkan imunitas udang belum menjadi prioritas utama. Peningkatan pertahanan tubuh ter-hadap serangan penyakit tidak hanya dapat dilakukan dengan pemberian pakan dengan komposisi nutrien yang seimbang, melainkan dapat juga disertai pemberian imunostimulan (bakteri dan produk bakteri, yeast, kompleks karbohidrat, faktor nutrisi, ekstrak hewan, ekstrak tumbuhan, dan obatobatan sintetik) dalam pakan.

Imunostimulan berhubungan langsung dengan sel sistem imun yang membuat sel tersebut lebih aktif (Irianto, 2005). Saat ini, penggunaan imunostimulan semakin men-dapat perhatian untuk dikembangkan sebagai metode kontrol penyakit dalam budidaya udang. Beberapa fakta menujukkan bahwa imunostimulan yang ditambahkan dalam pakan dapat me-ningkatkan resistensi ikan dan udang terhadap infeksi penyakit melalui peningkatan respon imun non spesifik (Pais et al., 2008).

Pemanfaatan beberapa bakteri dari tambak, air laut dan tubuh organisme sebagai probiotik yang berfungsi sebagai imunostimulan menunjukkan pengaruh positif terhadap pertumbuhan dan kesehatan ikan dan udang. Probiotik dapat menguntungkan dan dapat berperan secara baik berdasarkan mekanisme aksi pro-biotik yaitu produksi senyawa inhibitor, kompetisi terhadap senyawa kimia atau sumber energi, kompetisi terhadap tempat pelekatan, peningkatan sistem imun, perbaikan kualitas air dan interaksi dengan fitoplankton (Verschure et al., 2000). Beberapa bakteri yang telah berhasil digunakan sebagai probiotik antara lain Vibrio agliniticus (Gullian \& Rodríguez, 2004), Bacillus spp. (Moriarty, 1998) dan Thalassobacter utilis (Maeda \& Liao, 1992). Bakteribakteri tersebut bekerja dan berkompetisi dengan bakteri patogen pada udang. 
Salah satu bakteri yang dapat menjadi imunostimulan adalah bakteri Bacillus polymyxa yang telah diketahui mampu memproduksi zat polimiksin sebagai antibiotik (Shaheen et al., 2011). Bakteri tersebut tidak bersifat patogen dan berpotensi untuk dikembangkan menjadi probiotik pada sistem budidaya udang. Hasil penelitian Ravi et al. (2007) menyebutkan bahwa probiotik dari jenis Paenibacillus spp., Bacillus cereus dan Paenibacillus polymyxa yang diaplikasikan lewat air dapat menghambat pertumbuhan Vibrio pada larva udang windu (Penaeus monodon). Hasil penelitian Fajri (2017) menyebutkan bahwa perlakuan kombinasi bakteri Bacillus polymyxa dan Bacillus coagulans yang diaplikasikan lewat air dapat meningkatkan sintasan rata-rata sebesar $72 \%$ dibandingkan tanpa perlakuan sebesar $65 \%$. Penelitian mengenai aplikasi probiotik bakteri Bacillus polymyxa yang dicampur pakan terhadap imunitas non spesifik udang vannamei belum banyak dilakukan, sehingga perlu dilakukan penelitian mengenai pengaruh pemberian bakteri Bacillus polymyxa terhadap imunitas non spesifik udang vannamei.

\section{Metode}

Penelitian ini dilaksanakan pada bulan Mei - Juni 2017, bertempat di Laboratorium Perikanan dan Kelautan, Jurusan Perikanan dan Kelautan, Fakultas Pertanian, Universitas Lampung.

Alat yang digunakan pada penelitian ini meliputi wadah pemliharaan berupa akurium
$50 \times 40 \times 40 \mathrm{~cm}^{3}$, instalasi aerasi, $\mathrm{pH}$ meter, DO meter, mikropipet, spektro-fotometer, timbangan digital, tabung reaksi, labu erlenmeyer, labu ukur, jarum inokulan, bunsen, spuit 26G, kaca preparat, cover glass, mikrotube, yellow tip, mikropipet, alumunium foil, sprayer, hand tally counter, laminary airflow, hot plate stirrer, autoklaf, inkubator, haemacytometer dan waring. Sedangkan udang uji yang digunakan yaitu udang yang berbobot 10-12 gram, pakan komersil, air laut steril, akuades, $\mathrm{Na}$ sitrat $10 \%$, alkohol $70 \%, \mathrm{PBS}, \mathrm{NaCl}$ $0,85 \%$, safranin $10 \%$, bakteri Staphylococcus aureus, pewarna giemsa, molase, urea, media TSB, dan isolat bakteri Bacillus polymyxa.

Bakteri uji dipersiapkan dengan meng-kultur kembali bakteri Bacillus polymyxa pada media agar miring TSA (Tryptone Soy Agar) $70 \%$ air laut. Selanjutnya bakteri dikultur pada media cair TSB (Tryptone Soy Broth) $70 \%$ air laut untuk disimpan hingga waktu penggunaan. Bakteri dikultur pada media hingga mencapai kepadatan antara $10^{5}-10^{9} \mathrm{sel} / \mathrm{ml}$.

Hasil biakan bakteri dalam media TSB kemudian dikultur secara massal ke dalam 1 liter media yang terdiri dari campuran molase, urea dan akuades. Perhitungan kepadatan bakteri dilakukan dengan menggunakan metode turbiditymetri dengan mengukur absorbansi media menggunakan spektrofotometer (panjang gelombang $625 \mathrm{~nm}$ ) dan menghitung kepadatan menggunakan persamaan McFarland (Volk \&Wheeler, 1993) :

$$
Y=a X+b
$$


Keterangan:

$\mathrm{Y}=\operatorname{Kepadatan}(\mathrm{sel} / \mathrm{ml})$

$\mathrm{a}=2,62 \times 10^{9}$

$\mathrm{X}=$ Nilai absorbansi

$\mathrm{b}=6,39 \times 10^{7}$

Pakan udang vannamei yang digunakan adalah pakan komersil dengan kandungan protein $30 \%$, kemudian pakan disemprotkan bakteri Bacillus polymyxa sesuai dosis perlakuan, selanjutnya pakan dikering anginkan selama 5-15 menit, setelah itu pakan diberikan pada udang vannamei dengan metode ad satiation. Wadah untuk pemeliharaan adalah akuarium berukuran $50 \times 40 \times 40 \mathrm{~cm}$ sebanyak 12 buah. Akuarium diisi air laut sebanyak 50 liter dengan salinitas $30 \mathrm{ppt}$ dan diaerasi selama 24 jam. Setelah itu udang uji dimasukkan sebanyak 10 ekor/akuarium.

Pengambilan sampel haemolymph dilakukan pada hari ke0 , ke-5, ke-10, dan ke-15. Sampel diambil dari 4 ekor udang per perlakuan secara acak sebanyak 0,1 $\mathrm{ml}$ dari setiap sampel udang. Pengambilan sampel haemolymph dilakukan berdasarkan prosedur yang dikemukakan oleh Liu \& Chen (2004). Secara singkat, sekitar $0,1 \mathrm{ml}$ haemolymph diambil dari ventral sinus pada pangkal ruas tubuh pertama dengan menggunakan alat suntik $1 \mathrm{ml}$ yang sebelumnya dibilas antikoagulan (Na Sitrat 10\%). Kemudian haemolymph dimasukkan ke dalam mikrotube dan disimpan dalam cool box. Haemolymph tersebut akan didistribusikan untuk uji THC sebanyak $10 \mu 1$, AF sebanyak $20 \mu \mathrm{l}$ dan DHC sebanyak $10 \mu \mathrm{l}$.

Data hasil pengamatan meliputi Total Haemocyte Count (THC) dan aktifitas fagositosis (AF) dianalisis dengan uji normalitas dan homogenitas, kemudian dilakukan uji ANOVA. Jika hasil uji berbeda nyata maka dilakukan uji lanjut BNT pada selang kepercayaan 95\%. Parameter Differential Haemocyte Count (DHC) dan kualitas air dianalisis secara deskriptif.

\section{Hasil dan Pembahasan}

\section{Total Haemocyte Count (THC)}

Hasil perhitungan THC dapat dilihat pada Gambar 1.

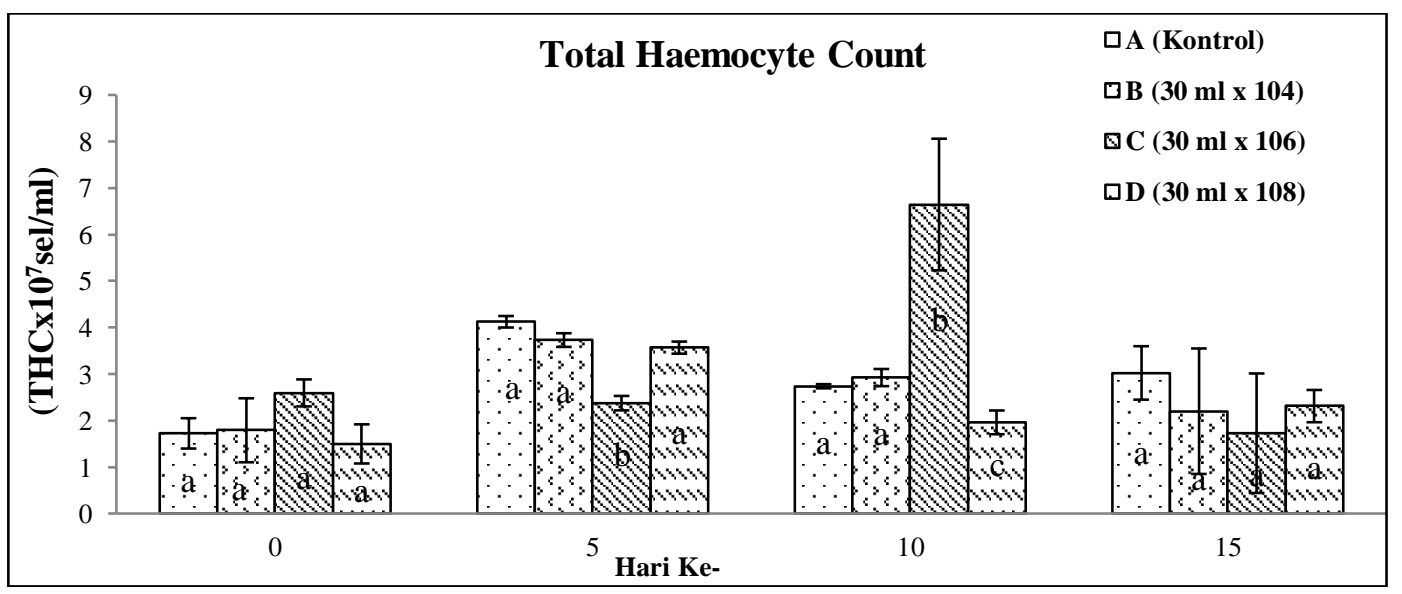

Gambar 1. Hasil perhitungan THC 
Gambar 1 menunjukkan bahwa THC terendah ditemukan pada hari ke-0 perlakuan D yaitu udang yang tidak diberi pakan buatan dengan campuran probiotik Bacillus polymyxa. Sedangkan THC tertinggi ditemukan pada hari ke-10 perlakuan $\mathrm{C}$ yang menunjukkan hasil berbeda nyata dengan perlakuan lainnya $(\mathrm{P}<0,05)$. Hasil analisis menunjukan bahwa pada hari ke-0 sampai hari ke hari ke-5 perlakuan A, B dan D memberikan pengaruh yang sama $(\mathrm{P}>0,05)$ terhadap jumlah hemosit udang vannamei, tetapi menunjukkan adanya peningkatan THC. Pada hari ke-10 perlakuan A dan B juga menunjukkan pengaruh yang sama $(\mathrm{P}>0,05)$ terhadap jumlah sel hemosit udang vannamei begitu juga pada hari ke-15 pada semua perlakuan. Hal ini diduga selama penelitian terjadi infeksi pada saat pengambilan hemolim pada udang. Adanya infeksi tersebut menyebabkan terjadinya peningkatan sel granular pada bagian tubuh udang yang terkena infeksi. Hal ini akan menyebabkan adanya perubahan THC pada udang (Van De Braak, 2002). Kemudian pendapat dari Anderson \& Siwicki (1995) pada saat terjadi infesksi sel darah akan bermigrasi ke daerah yang terinfeksi tersebut, hal ini menyebabkan pada saat pengambilan darah pada organ sirkulasi akan menyebabkan terdinya penurunan THC. Hal tersebut sesuai dengan pendapat dari Van de Braak (2002) yang mengatakan bahwa terjadi penurunan THC dan DHC pada sirkulasi darah udang jika terjadi infeksi, karena sel haemosit bermigrasi ke daerah di sekitar infeksi.
Hasil penelitian menunjukkan bahwa pemberian bakteri $B$. polymyxa mampu meningkatkan respon imun udang vannamei. Hasil penelitian juga me-nunjukkan nilai THC yang berbeda nyata pada hari ke-5 perlakuan C, dan pada hari ke-10 perlakuan $\mathrm{C}$ dan $\mathrm{D}(\mathrm{P}<0,05)$. Data THC pada Gambar 1. menunjukkan bahwa terjadi peningkatan jumlah THC pada hari ke-10 perlakuan C. Terjadinya peningkatan THC disebabkan karena molekul lectin yang merupakan bagian pertahanan imun udang yang berfungsi untuk melakukan pengenalan terhadap benda asing (non self recognition) yang masuk kedalam tubuh udang (Rodriguez \& Le Moullac, 2000). Sedangkan menurut Lopez et al. (2003), hemosit akan meningkat pada udang yang diberi pakan yang mengandung imuno-stimulan.

Menurut Chang et al. (1999) jumlah THC normal pada udang penaeid berkisar antara $2 \times 10^{7}-4 \times 10^{7}$ $\mathrm{sel} / \mathrm{ml}$. Hal ini sesuai dengan hasil penelitian yang didapatkan dengan nilai THC $1,4 \times 10^{7}-6,6 \times 10^{7} \mathrm{sel} / \mathrm{ml}$. Kisaran nilai THC pada penilitian ini masih dalam kisaran THC normal udang vannamei. Hal ini menunjukkan bahwa pakan yang diberikan probiotik $B$. polymyxa mampu mempertahankan total hemosit pada kisaran normal, yang berarti udang dalam kondisi sehat dan tidak stres.

\section{Aktifitas Fagositosis \\ Hasil rata-rata pengamatan aktifitas fagositosis pada tiap perlakuan dapat dilihat pada Gambar 2.}




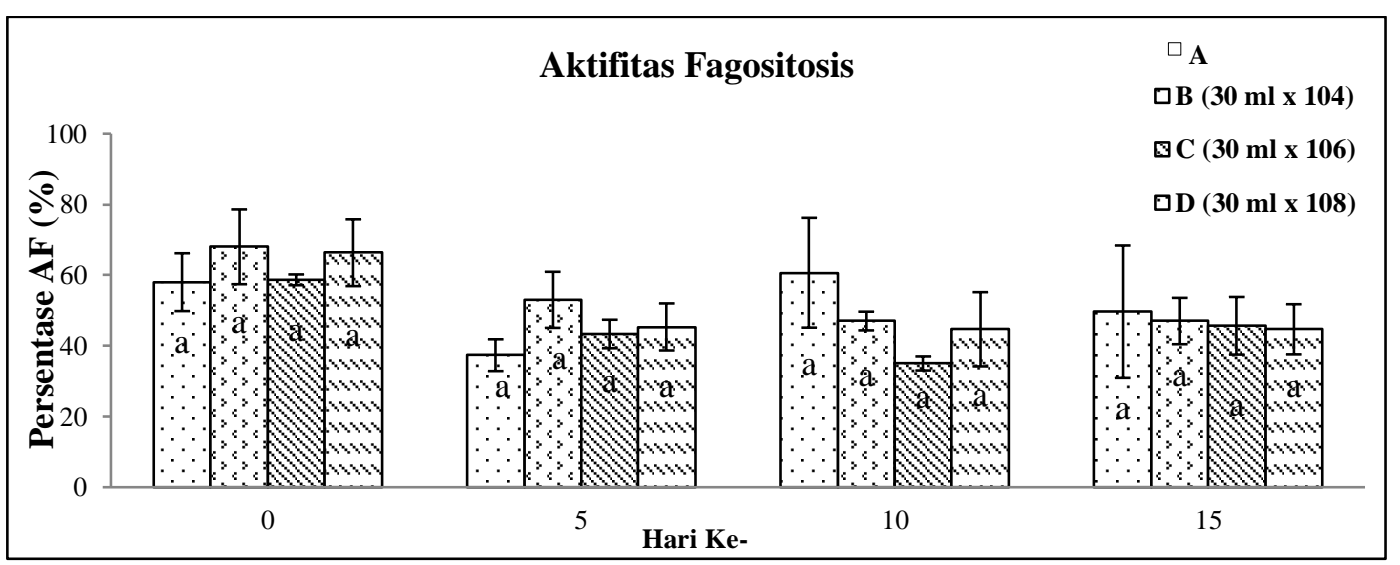

Gambar 2. Hasil perhitungan persentase aktifitas fagositosis

Untuk mengetahui bahwa hemosit merupakan pertahanan tubuh yang bersifat seluler dapat dilihat dari kemampuannya dalam aktivitas fagositosis yang dapat meningkat pada saat terjadi infeksi. Pemberian bakteri B. polymyxa sebagai probiotik pada penilitian ini menunjukkan hasil yang tidak berbeda nyata pada tiap perlakuan. Hasil analisis menunjukkan bahwa aktivitas fagositosis mengalami penurunan pada hari ke-5 sampai dengan hari ke-15. Peningkatan terjadi pada perlakuan A hari ke-10 dan perlakuan C pada hari ke-15. Peningkatan aktivitas fagositosis dari hemosit merupakan indikator meningkatnya pertahanan imun pada udang vannamei, masuknya benda asing dalam tubuh inang akan direspon dengan terjadinya proses fagositosis. Fagositosis merupakan mekanisme pertahanan non spesifik yang secara umum mampu melindungi dari serangan patogen (Syahailatua, 2009). Hasil rata-rata pengamatan aktivitas fagositosis pada tiap perlakuan dapat dilihat pada Gambar 2.

Hasil analisis menunjukkan bahwa semua perlakuan memberikan pengaruh yang sama $(\mathrm{P}>0,05)$ terhadap aktivitas fagositosis. Hasil tersebut menunjukkan bahwa pemberian probiotik $B$. polymyxa dengan dosis yang berbeda pada pakan memberikan pengaruh yang sama terhadap aktivitas fagositosis atau kemampuan sel respon imun non spesifik pada udang vannamei dalam memfagosit agen patogen. Hal tersebut juga didukung oleh pendapat Quinn et al. (2012) bahwa bakteri $B$. polymyxa hanya mampu memfagosit biofilm dari sel bakteri Staphylococus aureus sebesar 10-25\%. Staphylococus aureus merupakan bakteri penghasil koagulase yang diasosiasikan dengan patogenitas karena penggumpalan serat-serat benang yang tidak larut dalam plasma darah (fibrin), yang mengakibatkan enzim ini terakumulasi di sekitar bakteri sehingga agen pelindung inang kesulitan mencapai bakteri dan fagositosis terhambat (Madigan et al., 2008).

\section{Differential Haemocyte Count (DHC) \\ Hyalin}

Pada hasil pengamatan sel hyalin pada udang vannamei memiliki inti sel yang lebih besar dibandingkan sitoplasmanya dan memiliki granul- 
granul yang sangat sedikit bahkan tidak terdapat granul, serta bentuknya tidak beraturan. Hal ini sesuai dengan pendapat Syahailatua (2009) bahwa sel hyalin mempunyai bentuk yang tidak beraturan yang memiliki inti yang lebih besar dari sitoplasma dengan ukuran 6-13 $\mu \mathrm{m}$. Sel hyalin pada udang vannamei dapat dilihat pada Gambar 3.

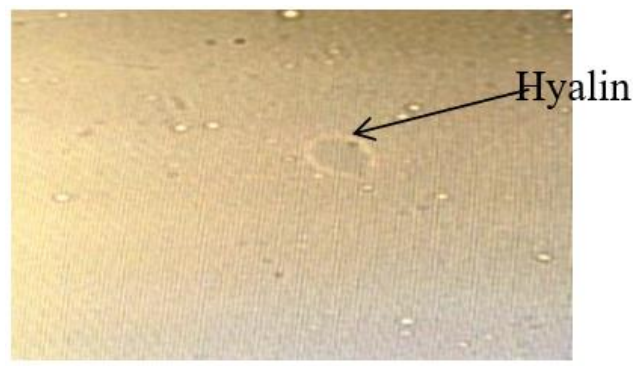

Gambar 3. Sel hyalin (Perbesaran 40x)

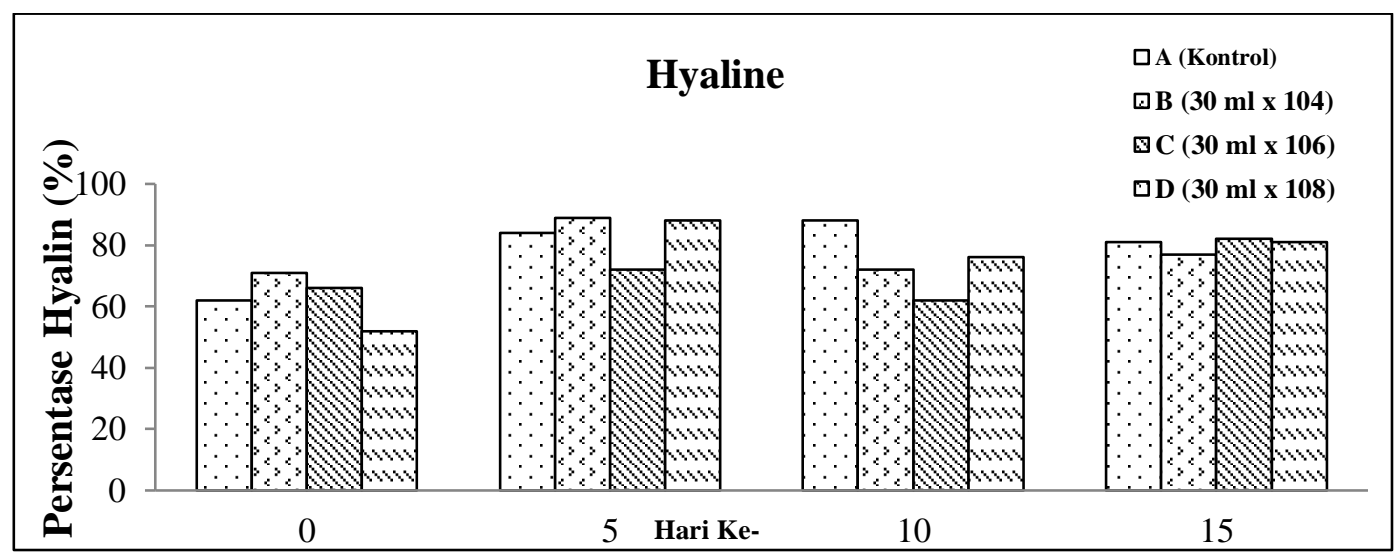

Gambar 4. Persentase jumlah sel hyalin

Gambar 4 menunjukkan bahwa persentase sel hyalin berada dalam kisaran 52\%-89\%. Sel hyalin tertinggi terdapat pada perlakuan B pada hari ke-5 sebesar 89\% (Gambar 4). Menurut Owens \& O’Neill (1997) persentase hyalin pada udang yang normal terdiri dari 60\%-93\% dari total hemosit. Hal ini menunjukkan bahwa sel hyalin pada udang uji masih dalam kondisi normal. Meningkatnya jumlah sel hyalin sesuai dengan pendapat Hauton (2012) bahwa sel hyalin juga berperan dalam fagositosis. Penurunan persentase sel-sel hyalin bukan merupakan pengaruh negatif dari pemberian probiotik Bacillus polymyxa tetapi merupakan implikasi dari peningkatan sel-sel granular.
Mekanisme pertahanan tubuh pada udang tidak seperti pada ikan dan mamalia yang mempunyai imunoglobulin. Imunoglobulin pada udang digantikan oleh Prophenoloxidase Activating Enzim (PPA) (Soderhall \& Cerenius, 1992). PPA adalah protein yang berlokasi di sel granular hemosit.

Dalam penelitian ini PPA tersebut diaktifkan oleh imunostimulan yang masuk ke dalam tubuh udang, yang akan merangsang prophenoloksidase menjadi phenoloksidase. Sebagai akibat dari perubahan ini akan dihasilkan protein Opsonin Factor yang dapat menginduksi sel-sel hyalin untuk meningkatkan aktivitasnya (Soderhall \& Cerenius, 1992). 


\section{Granular}

Pada hasil pengamatan sel granular pada udang vannamei memiliki bentuk yang bulat dan inti sel yang lebih kecil dibandingkan sitoplasmanya serta memiliki granulgranul. Hal ini sesuai dengan pendapat Syahailatua (2009) bahwa bentuk sel granular bulat dengan inti lebih kecil dari sitoplasma yang berisi butiran halus dengan ukuran 10-20

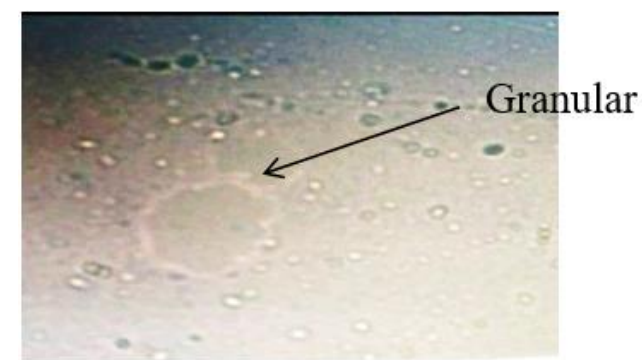

Gambar 5. Sel granular (Perbesaran 40x) $\mu \mathrm{m}$.

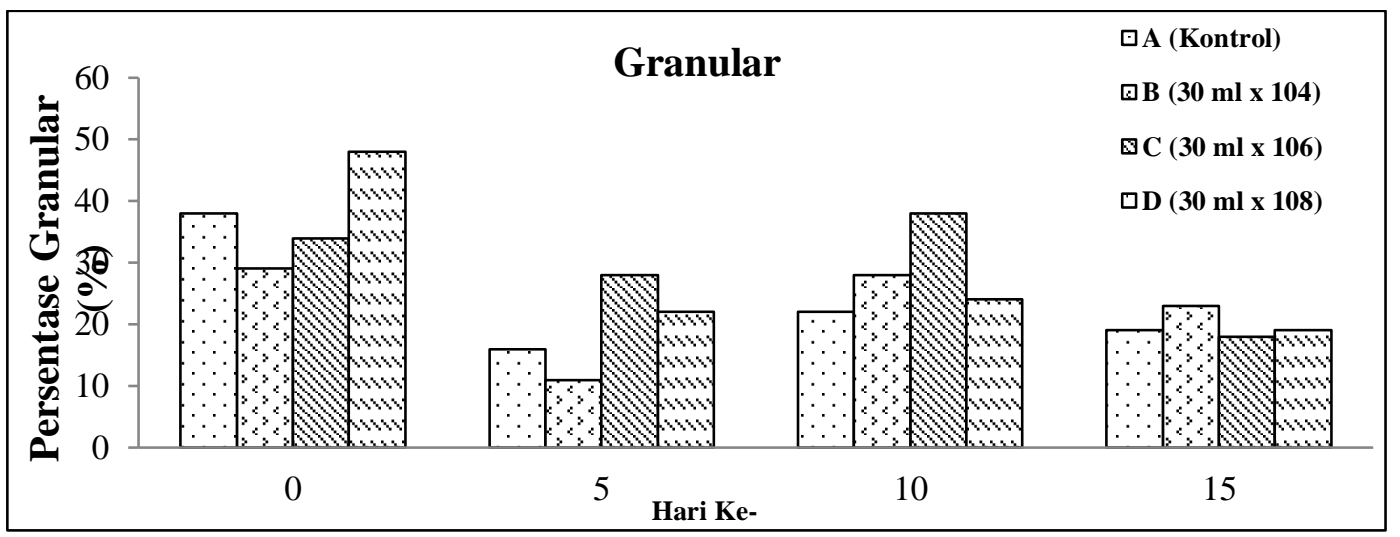

Gambar 6. Persentase jumlah sel granular

Hasil menunjukkan bahwa persentase sel granular berada dalam kisaran 11\%-48\%. Sel granular tertinggi terdapat pada perlakuan A hari ke-0 sebesar 48\% (Gambar 6). Menurut Owens \& O’Neill (1997) persentase granular pada udang yang normal terdiri dari $17 \%-40 \%$ dari total hemosit. Hal ini menunjukkan bahwa sel granular pada udang uji masih dalam kondisi normal. Terjadinya peningkatan dari sel granular disebabkan karena imunostimulan yang masuk ke dalam tubuh udang dapat menginduksi mekanisme pertahanan tubuh udang. Van de Braak (2002) menyatakan bahwa bahwa sel hemosit akan melakukan degranulasi, dan beberapa protein akan dilepas untuk kepentingan respon imun, seperti: meningkatnya sel haemosit, dan meningkatnya aktifitas penjeratan dan fagositosis. Imunostimulan yang masuk ke dalam tubuh udang akan merangsang haemosit untuk melepaskan proPO dan proteinbinding enzim PPA. Hal tersebut mengakibatkan sel hemosit meningkatkan aktifitasnya sebagai sel pertahanan tubuh.

\section{Kualitas Air}

Parameter kualitas air yang diukur selama penelitian meliputi temperatur (suhu), oksigen terlarut (DO), $\mathrm{pH}$ dan salinitas. Pengukuran dilakukan pada awal, tengah dan akhir masa pemeliharaan. Kisaran 
nilai kualitas air selama pemeliharaan disajikan pada Tabel 1.

Tabel 1. Nilai Kisaran Kualitas Air Media Pemeliharaan Udang Vannamei Pada Berbagai Perlakuan

\begin{tabular}{lcc}
\hline Parameter & $\begin{array}{l}\text { Kualitas Air Selama } \\
\text { Pemeliharaan }\end{array}$ & $\begin{array}{l}\text { Kisaran } \\
\text { Optimum } \\
\text { (SNI, 2006) }\end{array}$ \\
\hline Suhu ${ }^{\circ} \mathrm{C}$ & $27,2-28,1$ & $20,5-31,5$ \\
DO $(\mathrm{ppm})$ & $3,70-3,91$ & $>3,5$ \\
$\mathrm{pH}$ & $7,47-8,12$ & $7,5-8,5$ \\
Salinitas & $30-35$ & $15-25$ \\
(ppt) & & \\
\hline
\end{tabular}

Tabel 1 di atas menunjukkan bahwa salinitas yang didapat berkisar antara 30-35 ppt. Salinitas ini masih dianggap cukup baik pada pemeliharaan udang vannamei. Pada penelitian Sahrijanna \& Sahabuddin (2014) yang menggunakan probiotik pada pemeliharaan udang vannamei didapatkan hasil rata-rata kualitas air menggunakan probiotik yakni suhu $26,79^{\circ} \mathrm{C}$, oksigen $3,55 \mathrm{mg} / \mathrm{L}, \mathrm{pH} \mathrm{7,80}$ dan salinitas 34,12 ppt. McGraw \& Scarpa (2002) mengemukakan bahwa udang vannamei dapat hidup pada kisaran salinitas 0,5-45 ppt. Kualitas air media pemeliharaan selama penelitian berada pada kisaran yang ideal untuk pemeliharaan udang vannamei, sehingga diasumsikan perubahan respon imun yang meliputi parameter uji total haemocyte count (THC), aktivitas fagositosis (AF) dan differential haemocyte count (DHC) pada perlakuan bukan diakibatkan oleh kualitas air media pemeliharaan.

\section{Kesimpulan dan Saran}

Pemberian bakteri Bacillus
polymyxa dalam pakan udang
vannamei efektif untuk meningkatkan

Total Haemocyte Count (THC) udang vannamei.

\section{Daftar Pustaka}

Anderson, D.P \& Siwicki, A.K. 1995. Basic haematology and serology for fish health program. In: Diseases in Asian aquaculture II. M. Shariff, J. R. Arthur and R. P. Subasinghe (Eds). Fish Health Section, Asian Fisheries Society, Manila, 185-202 hal.

Chang, C.F. Su, M.S. \& Chen, H.Y. 1999. A rapid method to quantity total haemocyte count of penaeus monodon using ATP analysing. Fish Pathology, 34: 211-212.

Direktorat Jenderal Perikanan Budidaya (DJPB). 2015. Data produksi perikanan 2015. Statistik DJPB. 11 Februari 2015.

Fajri, N.M. 2017. Kajian efektivitas bakteri Bacillus coagulans dan Bacillus polymyxa terhadap pertumbuhan dan sintasan udang putih (Litopenaeus vannamei) yang dipelihara pada salinitas rendah. (Skripsi). Universitas Lampung, Lampung.

Gullian, M.F. Thompson \& Rodríguez, J. 2004. Selection of Probiotic bacteria and study of their immunostimulatory effect in Penaeus vannamei. Aquaculture, 233: 1-14.

Hauton, C. 2012. The scope of the crustacean immune system for disease control. Journal Invertebrata Pathology, 110: 251260.

Irianto, A. 2005. Patologi Ikan Telestoei. Gajah Mada University Press, Yogyakarta.

Kharisma, A \& Abdul, M. 2012. Kelimpahan Bakteri Vibrio sp. 
Pada Air Pembesaran Udang Vannamei (Litopenaeus vannamei) Sebagai Deteksi Dini Serangan Penyakit Vibriosis. Jurnal Ilmiah Perikanan dan Kelautan, (4) : 2.

Lee, M.H. \& Shiau, S.Y. 2004. Vitamin E Requirements of Juvenile Grass Shrimp, Penaeus monodon and Effects on Nonspecific Immune Responses, Fish \& Shellfish Immunology, 16: 475-485.

Liu, C.H. \& Chen, J.C. 2004. Effect of ammonia on the immune responsse of white shrimp Litopenaeus vannamei and its susceptibility to Vibrio alginolyticus. Fish \& Shellfish Immunology. 16: 321-334.

Lopez, N. Cuzon, G. Gaxiola, G. Taboada, G. Valenzuela, M. Pascual, C. Sánchez, A. \& Rosas, C. 2003. Physiological, nutritional, and immunological role of dietary ß-1,3-glucan and ascorbic acid 2monophosphate in Litopenaeus vannamei juveniles. Aquaculture, 224: 223-243.

Madigan, M.T. Martinko, J.M. Dunlap, P.V. \& Clark, D.P. 2008. Biology of Microorganisms 12th edition. San Francisco: Pearson.

Maeda, M. \& Liao, I.C. 1992. Effect of bacterial population on the growth of a prawn larva, Penaeus monodon. Bulletin of National Research Institute of Aquaculture, 21: 25-29.

McGraw, W.J. \& Scarpa, J. 2002. Determining ion concentration for Litopenaeus vannamei culture in freshwater. Global Aquaculture Advocate, 5: 36-37.

Moriarty, D.J. 1998. Control of luminous Vibrio species in penaeid aquaculture ponds. Aquaculture, 164: 351-358.

Owens, L. \& O'Neill, A.1997. Use of Clinical Cell Flow Cytometry for Differential Counts of Prawn (Penaeus monodon) Haemocytes. Diseases of Aquatic Organisms, 31: 147-153.

Pais, R. Khushiramani, R. \& Karunasagar, I. 2008. Effect of immunostimulants on hemolymph haemagglutinins of tiger shrimp Penaeus monodon. Aquaculture Research, 38: 1339-1345.

Quinn, G.A. Maloy, A.P. McClean, S. Carney, B.S. \& Slater, J.W. 2012. Lipopeptide Biosurfactants from Paenibacillus polymyxa Inhibit Single and Mixed Species Biofilms. Biofouling, 28(10): 1151-66.

Ravi, A.V. Musthafa, K.S. Jegathammbal, G. Kathiresan, K. \& Pandian, S.K. 2007. Screening and evaluation of probiotics as a biocontrol agent against pathogenic Vibrios in marine aquaculture. Applied Microbiology, 45: 219-22.

Ridlo, A. \& Pramesti, R. 2009. Aplikasi Ekstrak Rumput Laut sebagai Agen Imunostimulan Sistem Pertahanan Non Spesifik pada Udang Vannamei (Litopennaeus vannamei). Ilmu Kelautan, 14(3): 133-137.

Rodriguez, J. \& Le Moullac, G. 2000. State of The Art of Immunological Tools and Health Contol of Penaeid (Penaeus monodon). PhD Thesis, Wageningen University. Netherland.

Sahrijanna, A. \& Sahabuddin. 2014. Kajian Kualitas Air Pada Budidaya Udang Vaname (Litopenaeus Vannamei) Dengan Sistem 
Pergiliran Pakan Di Tambak Intensif . Balai Penelitian dan Pengembangan Perikanan Budidaya Air Payau. Prosiding Forum Inovasi Teknologi Akuakultur. Sulawesi Selatan.

Shaheen, M. Li, J. Ross, A.C. Vederas, J.C. \& Jensen, S.E. 2011. Paenibacillus polymyxa PKB1 Produces Variants of Polymyxin Btype Antibiotics. Chemistry \& Biology, 18(12): 1640-1648.

SNI, 2006. Produksi udang vannamei (Litopenaeus vannamei) ditambak dengan teknologi intensif. Jakarta: Badan Standarisasi Nasional : SNI-01-7246-2006.

Soderhall, K. \& L. Cerenius. 1992. Crustacean immunity. Annual Review of Fish Disease, 2: 3-23.

Syahailatua, D.Y. 2009. Seleksi Bakteri Probiotik sebagai Stimulator Sistem Imun pada Udang Vannamei (Litopenaeus vannamei). (Tesis). Sekolah Pascasarjana. Institut Pertanian Bogor. Bogor, 58 hal.

Van de Braak, K. 2002. Hemocytic Defence in Black Tiger Shrimp (Penaeus monodon). Disertasi, Wageningen University, Wageningen Institute of Animal Source Science, Wageningen, Netherlands.

Verschure, L. Rombaut, G. Sorgeloos, P. \& Verstraete, W. 2000. Probiotic bacteria as biological control agents in aquaculture. Microbiology and Molecular Biology Reviews, 64(4): 655-671.

Volk, \& Wheeler. 1993. Dasar-Dasar Mikrobiologi. Erlangga. Jakarta. 
